\title{
Integrated Management of Bacterial Spot on Tomato in Florida ${ }^{1}$
}

\author{
Amanda Strayer-Scherer, Ying-Yu Liao, Peter Abrahamian, Sujan Timilsina, Mathews Paret, Tim \\ Momol, Jeff Jones, and Gary Vallad²
}

\section{Introduction}

Bacterial spot is one of the most detrimental diseases of tomato and is present worldwide wherever tomatoes are grown. Bacterial spot of tomato is especially severe in the southeast United States when weather conditions (high temperature, high humidity, and rain) become conducive for disease development. The disease was first observed in South Africa in 1914, and the causal agent has undergone several name changes since (Doidge 1920). Four distinct species of Xanthomonas are associated with bacterial spot on tomato: X. euvesicatoria, X. vesicatoria, X. perforans, and $X$. gardneri, which were formerly grouped together and referred to as Xanthomonas campestris pv. vesicatoria (Jones et al. 2004). Due to the wide diversity within the bacterial spot disease complex, it can cause disease in different temperatures and has become a threat to tomato production worldwide. Of the four species, $X$. perforans is the dominant cause of bacterial spot on tomato in Florida. To date, neither X. vesicatoria nor X. gardneri has been found in Florida, and recent surveys of tomato have not found any $X$. euvesicatoria.

\section{Symptoms}

Symptoms of bacterial spot can affect all aboveground plant parts. Spots are generally dark brown to black and circular (but can be angular) on the leaves (Figure 1) and stems (Figure 2). Disease usually starts on the lower leaves, and symptoms are initially more visible on the underside of the leaves. Leaf lesions are initially circular and water-soaked (Figure 3), later turning dark brown to black with a wet or greasy appearance (Ritchie 2000; Vallad et al. 2004). A developing lesion may have a faint halo (Figure 4), which eventually disappears (Jones 1991; Kucharek 1994). Spots rarely develop to more than $3 \mathrm{~mm}$ in diameter. In some cases of $X$. perforans infections, the dead tissue in the center of a lesion can drop out, giving the lesion a "shot hole" appearance (Figure 5). When conditions are optimal for disease development, primary lesions can coalesce to form

1. This document is PP353, one of a series of the Plant Pathology Department, UF/IFAS Extension. Original publication date November 2019. Visit the EDIS website at https://edis.ifas.ufl.edu for the currently supported version of this publication.

2. Amanda Strayer-Scherer, graduate research assistant; Ying-Yu Liao, graduate research assistant, Plant Pathology Department, North Florida Research and Education Center, UF/IFAS Extension, Quincy, FL 32351; Peter Abrahamian, postdoctoral researcher, Plant Pathology Department, Gulf Coast Research and Education Center, UF/IFAS Extension, Wimauma, FL 33598; Sujan Timilsina, postdoctoral researcher, Plant Pathology Department, UF/IFAS Extension, Gainesville, FL 32611; Mathews Paret, associate professor, Plant Pathology Department, North Florida REC, UF/IFAS Extension, Quincy, FL 32351; Tim Momol, professor; Jeff Jones, professor, Plant Pathology Department, UF/IFAS Extension, Gainesville, FL 32611 ; and Gary Vallad, associate professor, Plant Pathology Department, Gulf Coast REC, UF/IFAS Extension, Wimauma, FL 33598.

The use of trade names in this publication is solely for the purpose of providing specific information. UF/IFAS does not guarantee or warranty the products named, and references to them in this publication do not signify our approval to the exclusion of other products of suitable composition. All chemicals should be used in accordance with directions on the manufacturer's label.

Use pesticides safely. Read and follow directions on the manufacturer's label.

The Institute of Food and Agricultural Sciences (IFAS) is an Equal Opportunity Institution authorized to provide research, educational information and other services

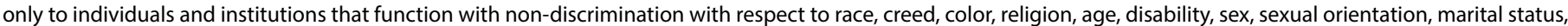
national origin, political opinions or affiliations. For more information on obtaining other UF/IFAS Extension publications, contact your county's UF/IFAS Extension office. U.S. Department of Agriculture, UF/IFAS Extension Service, University of Florida, IFAS, Florida A \& M University Cooperative Extension Program, and Boards of County Commissioners Cooperating. Nick T. Place, dean for UF/IFAS Extension. 
irregularly shaped lesions and areas of extensive necrosis. A general yellowing and blighting may occur on leaflets with many lesions. Bacterial spot lesions can also develop along leaf margins as the pathogen infects leaf hydathodes, resulting in blackening of the leaf margins and foliar blighting. Dead foliage will often remain on the plant, which can give it a scorched appearance (Figure 6). Fruit lesions begin as small, slightly raised blisters. As spots increase in size, they become dark brown, scab-like, and slightly raised (Figure 7). However, they may also be raised around the margins and sunken in the middle.

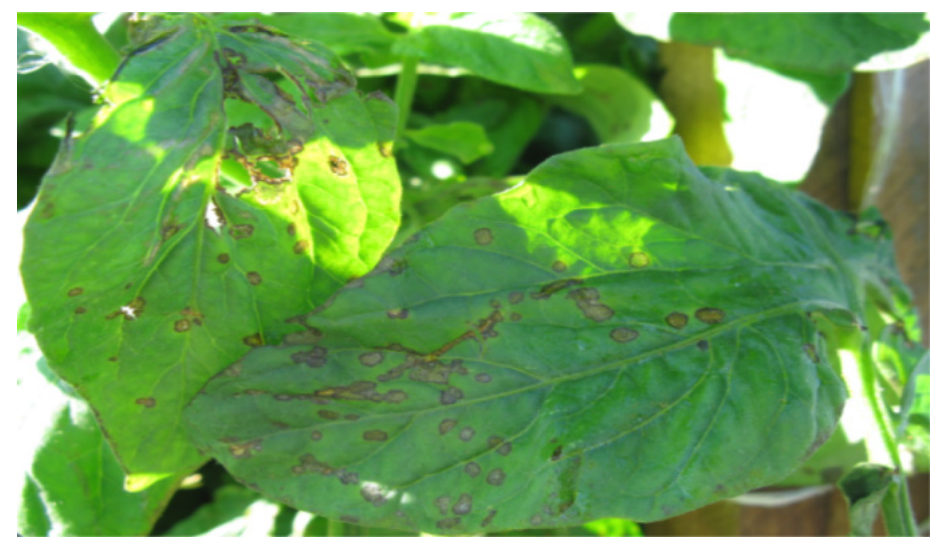

Figure 1. Leaf spots on tomato leaves caused by $X$. perforans. Credits: Gary Vallad, UF/IFAS

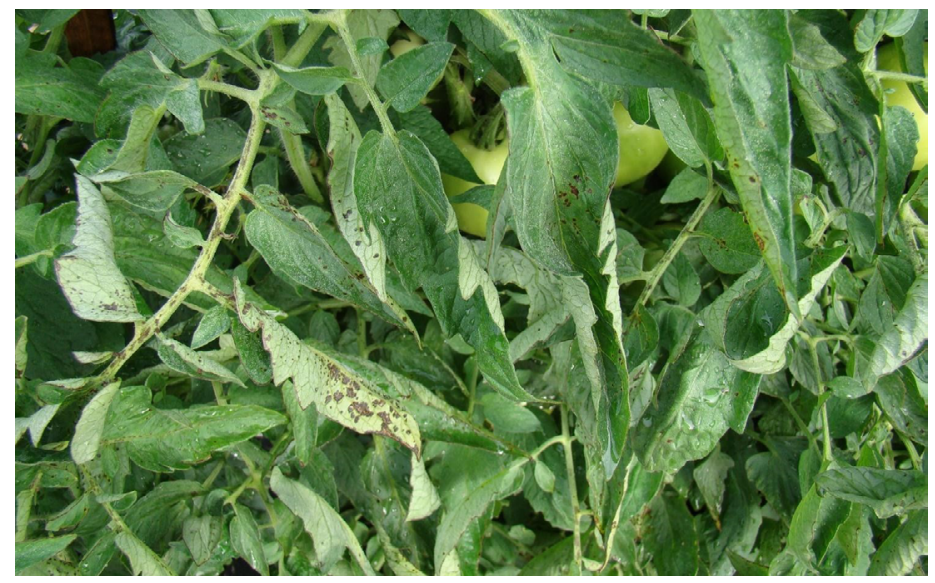

Figure 2. Stem lesions on tomato caused by X. perforans.

Credits: Mathews Paret, UF/IFAS

On leaflets, the spots can easily be confused with early symptoms of bacterial speck and several diseases caused by fungi, including early blight, gray leaf spot, or target spot. Under a light microscope, an ooze can be observed streaming from excised lesions (Figure 8) and is referred to as bacterial streaming. In contrast, lesions caused by fungal diseases do not exhibit streaming. In addition, lesions of early blight and target spot typically develop concentric zones as they expand. Gray leaf spot lesions are lighter in color and more uniformly distributed than bacterial spot lesions.

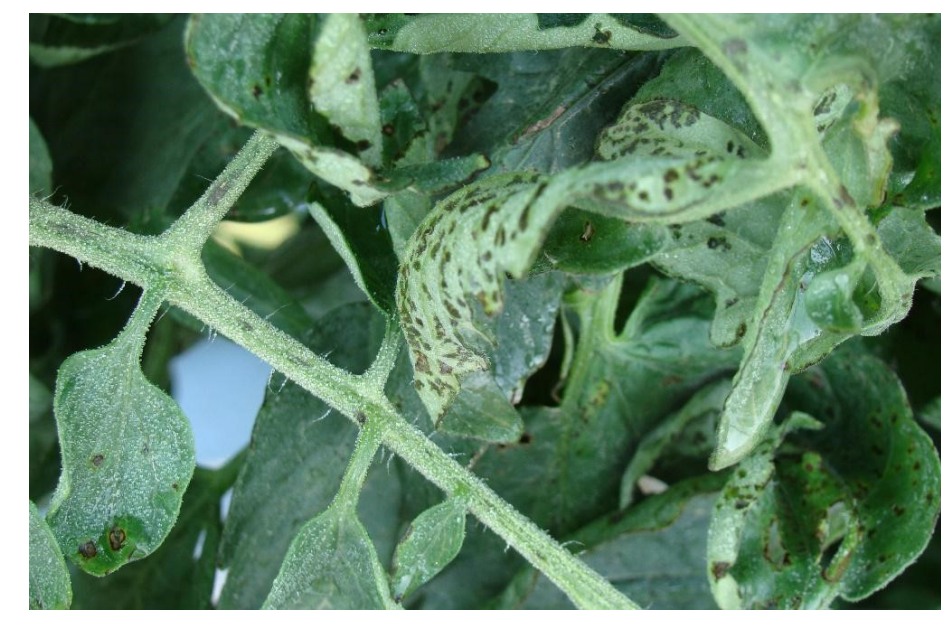

Figure 3. Water-soaking symptoms on the underside of leaves caused by $X$. perforans.

Credits: Mathews Paret, UF/IFAS

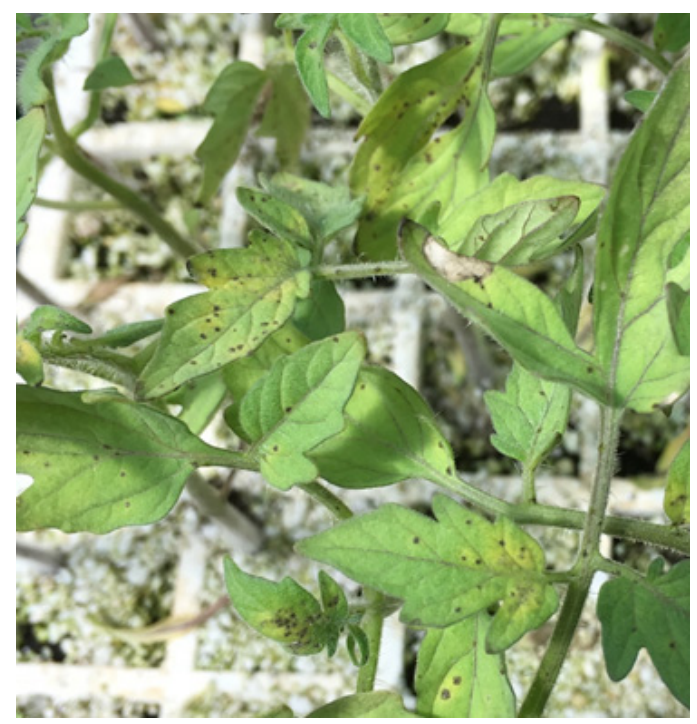

Figure 4. Pinpoint lesions with halo of $X$. perforans on tomato transplant seedlings.

Credits: Peter Abrahamian, UF/IFAS

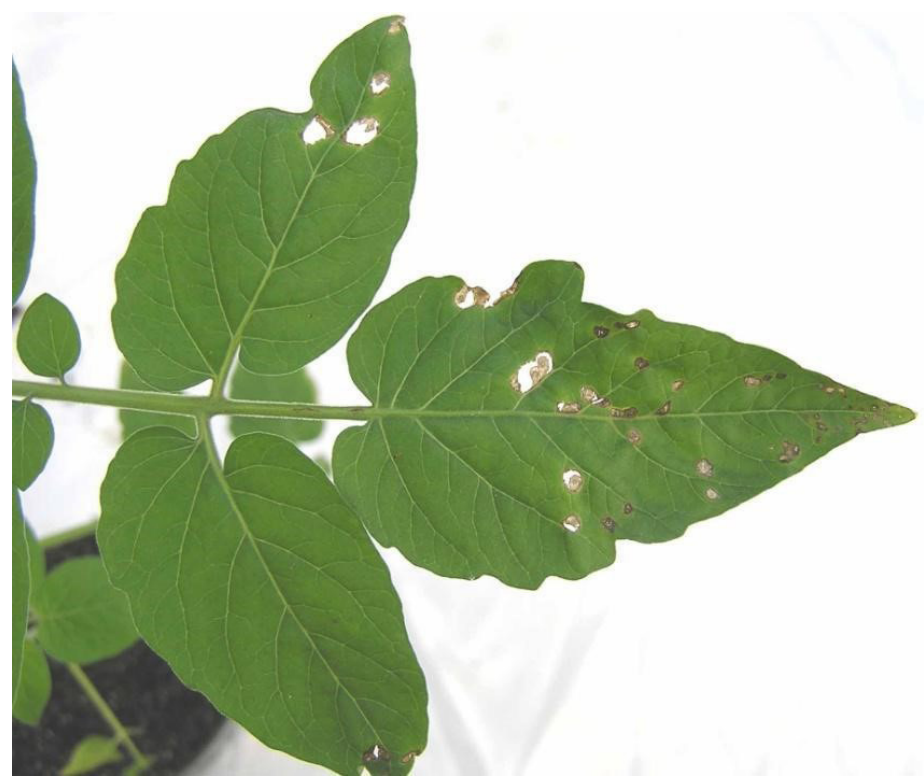

Figure 5. Leaf spots with shot-hole appearance caused by $X$. perforans. Credits: Jeff Jones, UF/IFAS 


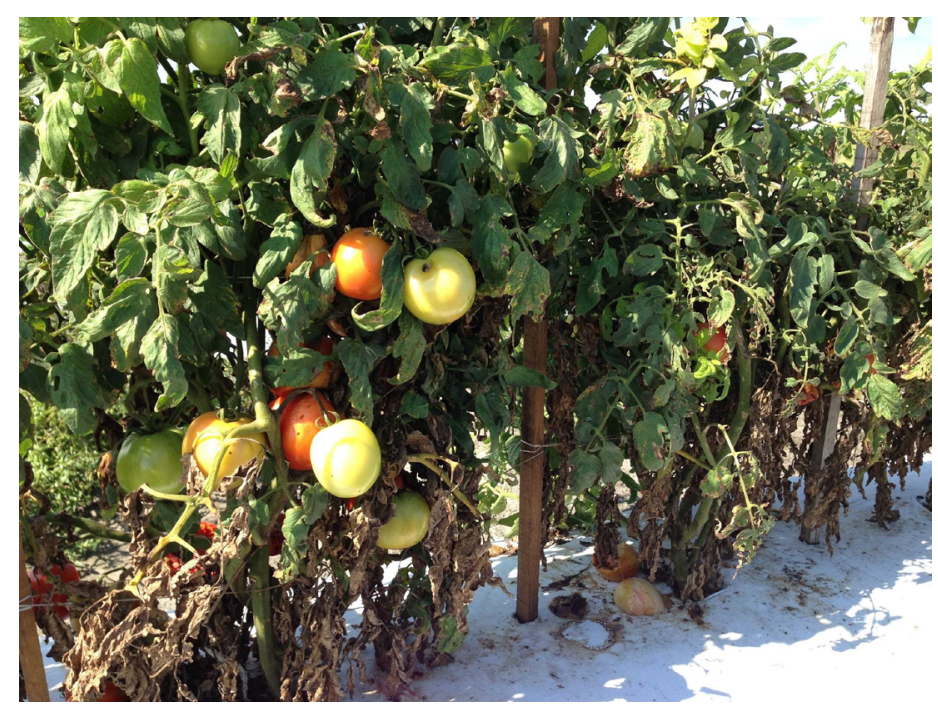

Figure 6. Scorched appearance of leaves at the bottom of the tomato canopy.

Credits: Peter Abrahamian, UF/IFAS

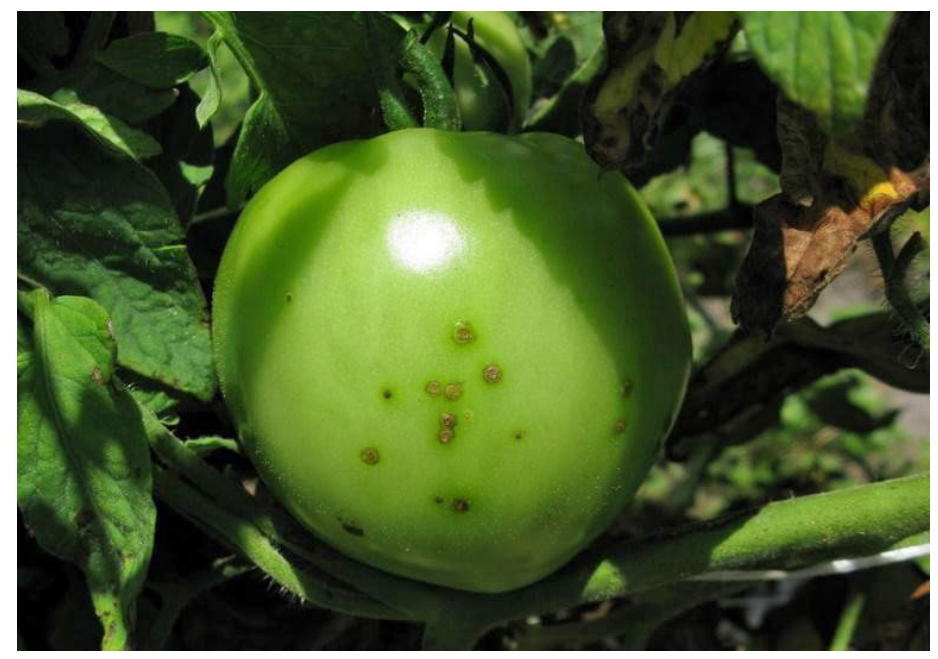

Figure 7. Lesions on tomato fruit.

Credits: Gary Vallad, UF/IFAS

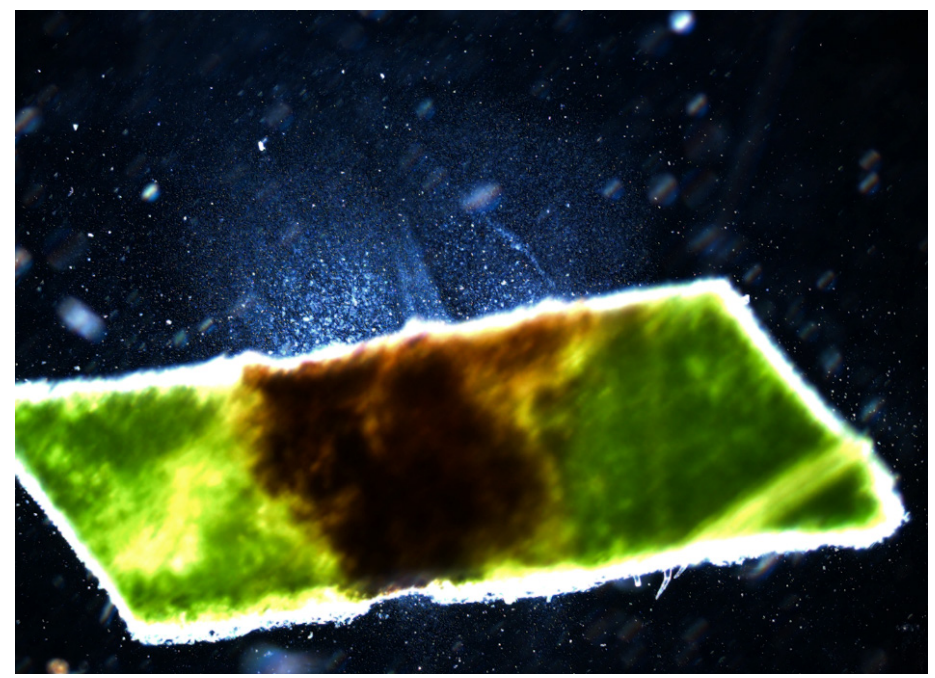

Figure 8. View of diseased tissue under microscope exhibiting bacterial streaming.

Credits: Gary Vallad, UF/IFAS

\section{Causal Organism}

All four Xanthomonas species associated with bacterial spot of tomato are strictly aerobic, gram-negative rods and motile with a single polar flagellum. On nutrient agar, these Xanthomonas species grow relatively slowly and produce colonies that are circular, wet, shiny, and yellow (Figure 9) (Doidge 1921).

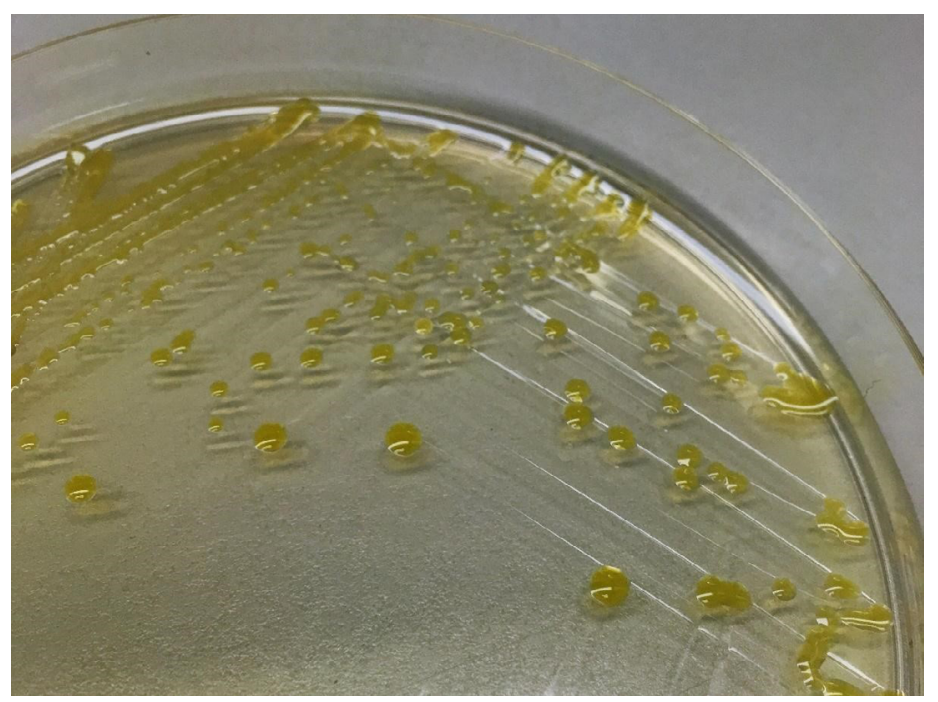

Figure 9. Xanthomonas colonies on nutrient agar.

Credits: Peter Abrahamian, UF/IFAS

On tomato, this pathogen consists of four races that correspond to different species; tomato race 1 (T1) corresponds to $X$. euvesicatoria, race 2 (T2) corresponds to $X$. vesicatoria and X. gardneri, and races 3 (T3) and 4 (T4) both correspond to $X$. perforans. Prior to the early 1990s, only $X$. euvesicatoria race $\mathrm{T} 1$ was associated with bacterial spot in Florida until the discovery of $X$. perforans race T3 (Stall et al. 2009). X. perforans race T4 emerged by the mid-1990s in Florida and is now the dominant race isolated from Florida tomato. Neither X. vesicatoria, nor X. gardneri have ever been found in Florida, although both species are present in production areas in the American Midwest and Canada (Jones 1991; Horvath et al. 2012; Ma et al. 2011).

\section{Detection and Identification}

The bacteria can be easily isolated from infected plant tissue by streaking onto nutrient agar, sucrose peptone, or yeast-dextrose-calcium carbonate agar (YDC) and produce yellow, mucoid, and convex colonies (Doidge 1921; Potnis et al. 2015). Several biochemical and physiological tests can be used to characterize the bacterial spot pathogens. The bacteria are catalase positive and oxidase negative (Obradovic et al. 2004). Strains of $X$. euvesicatoria and X. gardneri are weakly amylolytic and pectolytic, whereas strains of $X$. vesicatoria and $X$. perforans are strongly amylolytic and pectolytic (Bouzar et al. 1994a; Bouzar et al. 1994b; Jones et al. 2004). 


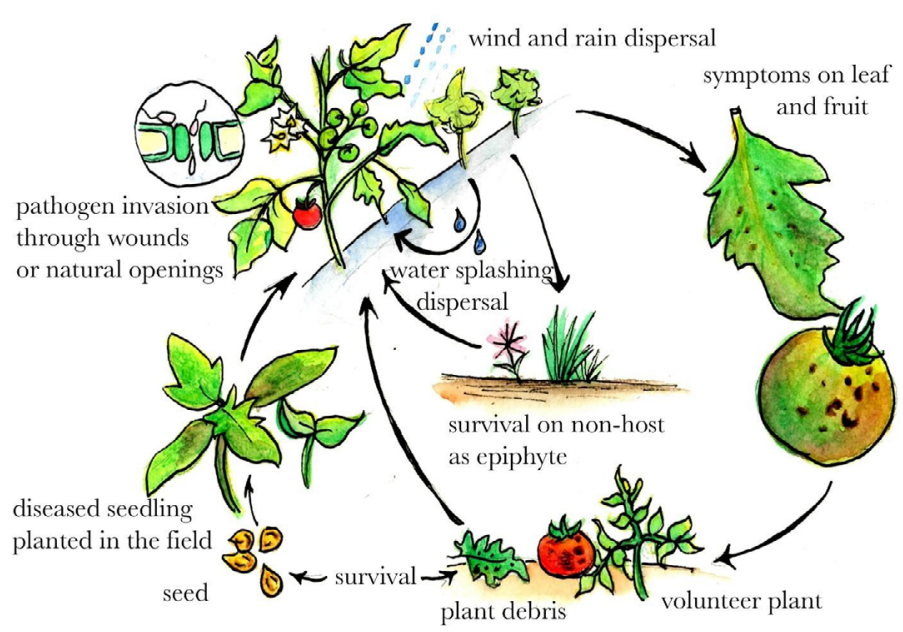

Figure 10. Bacterial spot of tomato disease cycle. Credits: Ying-Yu Liao, UF/IFAS

Several molecular identification techniques developed for the detection and identification of the bacterial spot pathogens are available. Polymerase chain reaction (PCR) assays can differentiate between bacterial spot species (Araújo et al. 2012; Cuppels et al. 2006; Koenraadt et al. 2009; Obradovic et al. 2004). More specifically, Araújo et al. (2012) developed a multiplex PCR that effectively differentiates and identifies strains from the four bacterial spot species. Additionally, Strayer et al. (2016) designed a multiplex real-time PCR assay to simultaneously detect and differentiate all four bacterial spot pathogens. This technique saves time when processing large sample numbers in comparison to gel electrophoresis detection techniques.

\section{Disease Cycle and Epidemiology}

Seed, tomato volunteers, and plant debris from infected plants are sources of bacterial spot inoculum (Jones et al. 1986). Disease development is favored by temperatures ranging between $75.2^{\circ} \mathrm{F}-86^{\circ} \mathrm{F}$ and high humidity. The dissemination of the bacterium within fields occurs by winddriven rain or irrigation droplets and aerosols, and also by some cultural practices. Handling plants while the foliage is wet will help disseminate the bacteria (Pohronezny et al. 1990). The bacterium enters through natural openings (e.g., stomata and hydathodes) and wounds created by winddriven sand, insect punctures, or mechanical means (Jones 1991). The bacterium can be recovered from nonsymptomatic plants in as early as one week at distances of up to $4 \mathrm{~m}$ from neighboring symptomatic plants. Due to the use of overhead irrigation systems in the greenhouse, bacterial spot can be spread rapidly during commercial seedling production, up to $2 \mathrm{~m}$ within three weeks from initial plant infection. Under optimal conditions, symptoms on tomato seedlings develop within five days after initial infection.

\section{Disease Management Cultural Practices}

Pathogen-free certified seed and disease-free transplants are recommended as the primary management strategies (Ritchie 2000). Elimination of solanaceous weeds such as ground cherry and nightshade in and around tomato fields is also recommended (Kucharek 1994). Other inoculum sources, including volunteer tomato and infected tomato plants or residue, should be removed or destroyed on a timely basis. Crop rotation should be used to avoid carryover on volunteers and crop residue (tomato and pepper). Do not establish cull piles near field operations. Do not spray, tie, harvest, or handle wet plants. In the greenhouse, rogue trays within 1 to $2 \mathrm{~m}$ from outbreak locations.

\section{Chemical Control}

Several chemicals, including copper-based fungicides, systemic acquired resistance (SAR) inducers, and various antibiotics, are labeled for use in tomato production. Growers should refer to the Florida Vegetable Production Handbook for a list of conventional products labeled for bacterial spot on tomato (http://edis.ifas.ufl.edu/cv292).

\section{COPPER}

Copper has been used as a fungicide to manage plant pathogens since the early 1800 s. When solubilized in water, copper ions bind tightly to sulfhydryl groups, accounting for its biocidal properties. Originally, growers relied on the application of streptomycin, an antibiotic, with copperbased fungicides to manage bacterial spot. However, the emergence of streptomycin-resistant Xanthomonas strains severely reduced its efficacy in the 1960s. By the 1980s, strains exhibiting tolerance to copper emerged, which limited the effectiveness of copper-based fungicides (Marco and Stall 1983; Thayer and Stall 1961). As a result, control of bacterial spot was only achievable with the addition of mancozeb, an eythylene-bis-dithiocarbamate, to the tank mix with copper bactericides (Conover and Gerhold 1981; Marco and Stall 1983). Since then, copper-mancozeb mixtures have been the standard practice for controlling bacterial spot.

In an attempt to manage the disease, Florida growers apply copper-mancozeb mixtures two or more times per week in a fall season. Various copper-based fungicides exist on the market (Table 1). The exact amount of copper can vary greatly among formulated products based on the amount of copper in each formulation, as represented by metallic copper content. In 2011, the EPA changed copper labeling by introducing limitations on the amount of copper that 
can be applied on tomatoes for a single application to 1.6 $\mathrm{lb}$ metallic copper per acre $\left(\mathrm{Cu}^{2+} / \mathrm{Acre}\right)$ and established a maximum annual application rate of $8.0 \mathrm{lb}$ metallic copper per acre $\left(\mathrm{Cu}^{2+} / \mathrm{Acre}\right)$ (EPA 2009). These restrictions included changes to re-entry restriction intervals and personal protective equipment. Furthermore, copper-based fungicides are protectants, meaning they only affect bacteria on plant surfaces, and therefore must be used as part of an integrated pest management program. However, until recently, few options were available that could be integrated with copper-based fungicides for bacterial spot control on tomato. Recent field trials evaluating alternative chemicals like acibezolar-S-methyl (Actigard, Syngenta, NC) significantly reduced bacterial spot disease severity when compared to nontreated controls (Abrahamian et al. 2019).

Historically, commercially available copper fungicides typically contain metallic copper in the form of insoluble copper compounds, such as copper (II) hydroxide, copper (II) oxide, or copper (II) oxychloride (Young and Santra 2014). Recently, novel copper formulations such as copper octanoate (Cueva, Certis USA, MD) and copper-based nanomaterials have been evaluated as potential alternatives to other commercially available copper fungicides. Greenhouse applications of copper octanoate provided superior control of a copper-tolerant bacterial strain in comparison to copper hydroxide but were ineffective under field conditions (Abrahamian et al. 2019). Furthermore, Strayer-Scherer et al. (2017) evaluated the ability of three copper-based nanomaterials to manage bacterial spot of tomato. Under greenhouse conditions, all three copperbased nanomaterials significantly reduced bacterial spot disease severity caused by a copper-tolerant strain of $X$. perforans when compared to copper-mancozeb and water controls. Although there was no significant impact on yield, copper composites significantly reduced disease severity when compared to water controls using $80 \%$ less metallic copper in comparison to copper-mancozeb in field studies. However, these copper nanomaterials are still being evaluated for commercial readiness.

In general, there are some disadvantages involving the use of copper-based fungicides to manage bacterial spot of tomato, such as toxicity to plants (referred to as phytotoxicity), nontarget environmental impacts, and the presence of copper-resistant bacterial strains. Free copper ions can penetrate through the plant cuticle and cause severe phytotoxicity. Water-insoluble (or low-soluble) copper salts ("fixed coppers") minimize this problem and have become the predominant chemical group for bacterial disease control. In the environment, copper ions are not degraded in soil and can accumulate to high levels at locations with a history of intense copper usage (Koller 1998). Under optimal disease conditions, copper-mancozeb fails to adequately control bacterial spot when copper-tolerant strains are present (Jones and Jones 1985; Obradovic et al. 2005). Surveys conducted in 2006-2007 and 2011-2012 of tomato production areas throughout Florida characterized 377 and 176 Xanthomonas strains, respectively, and determined that all strains were $X$. perforans and tolerant to copper (Horvath et al. 2012; Timilsina et al. 2012).

\section{SAR INDUCERS}

Systemic acquired resistance (SAR) is a biochemical state of enhanced resistance in which the plant's innate defenses are activated against a pathogen by a previous infection of the same or different pathogen (Sticher et al. 1997). Several compounds that induce SAR, such as the compound acibenzolar-S-methyl (ASM), have been thoroughly investigated. ASM has shown activity against bacterial spot in tomato in Florida, Alabama, North Carolina, Ohio, and Ontario, Canada (Louws et al. 2001). Recently, field trials in Florida evaluated a range of application rates and frequencies for ASM to optimize bacterial spot control, caused by X. perforans (Huang et al. 2012). The study found that weekly applications of ASM were statistically superior to a 14-day application interval and gave equivalent or better control than the copper-mancozeb standard. Drip applications of ASM were more effective than foliar applications and standard copper sprays (Huang and Vallad 2012). Previous studies also found that integration of ASM with phage applications resulted in significant increases in disease control compared to the standard bacteriophage and copper-mancozeb treatments (Balogh et al. 2002; Obradovic et al. 2002). ASM significantly reduced bacterial spot in seedling transplants under greenhouse conditions (Abrahamian et al. 2019). Regardless of disease control, ASM had no significant effect on tomato yields compared to standard copper sprays or nontreated controls.

\section{ANTIBIOTICS}

Only a limited number of antibiotics are labeled for transplant production for the management of bacterial spot. Currently, streptomycin is limited for use in transplant facilities only. Streptomycin was used for disease management during the 1950s and early 1960s. However, previous studies reported high distribution of streptomycinresistant bacteria strains (Thayer and Stall 1962). Recently, kasugamycin was described as a novel antibiotic for use against bacterial spot of tomato (Wade and Kurtz 2006). A commercial formulation of kasugamycin, Kasumin 2L 
(Ayrsta LifeScience, Tokyo, Japan), significantly reduced bacterial spot in tomato compared to the standard disease management practice of using copper bactericides (Vallad et al. 2010). Combining kasugamycin with other commercial products like chlorothalonil and copper hydroxide was reported to increase total marketable yield of tomato compared to standard copper management (Ivors et al. 2006).

\section{Biological Control}

Commercially available strains of Bacillus spp. and Streptomyces spp. and other biopesticides are labeled for bacterial spot. In general, these products have not been consistent in their performance in field tests across locations within Florida. However, many of these products are OMRI listed and approved for organic production. Growers can refer to the Florida Vegetable Production Handbook for a list of biopesticides and alternative disease management products labeled for bacterial spot on tomato (http://edis.ifas.ufl.edu/ cv292).

Bacteriophages (phages) can be effective biocontrol agents for the management of bacterial spot on tomato (Flaherty et al. 2000). Phages are viruses that infect bacteria. Protective formulations were developed to increase longevity of phages on plant surfaces in the field (Balogh et al. 2002). Early research trials showed evening applications of phages to be effective compared to morning applications. Jones et al. (2002) tested bacteriophages for control of the bacterial spot pathogen on tomato. Bacteriophage performance under field conditions was not consistent. In prior studies, tomato plants sprayed with phage at rates of $1 \times 10^{8} \mathrm{pfu} / \mathrm{ml}$ exhibited reduced levels of bacterial spot severity compared to plants treated with copper-mancozeb or the untreated control. Recent field trials showed that AgriPhage (Certis USA, MD), a registered bacteriophage mixture, was not effective in reducing disease compared to nontreated or copper sprays in field trials. In transplant seedlings grown under greenhouse conditions, AgriPhage applications did not reduce disease compared to copper or nontreated plants (Abrahamian et al. 2019). Although commercial bacteriophages are readily available, their cost and inconsistent efficacy pose a significant drawback for adoption into a spray program.

\section{Integrated Management}

To manage bacterial spot in tomato production, producers must incorporate several disease management strategies into an integrated pest management (IPM) program. There are two important approaches to reduce the severity and incidence of bacterial spot in the field: 1 ) reducing inoculum and 2) minimizing plant susceptibility. To prevent pathogen carryover from the previous season, cultural practices involving field hygiene are necessary to minimize the survival of bacteria on tomato debris, volunteer tomatoes, and related weed species. Using healthy, disease-free transplants is also important to minimize inoculum at the beginning of the season. Beginning the season with diseasefree transplants, especially for fall production, is one of the greatest challenges for growers and transplant producers alike. Conditions within transplant production facilities are highly conducive for bacterial spot, especially during the summer months. Based on recent research, rotation or tank-mix applications of Actigard and Cueva on transplants provide good disease control and are suitable alternatives to the grower standard. For field production, Actigard has emerged as an effective product on the market for bacterial spot management in tomato through repeated research and farm trials. Although previous studies found advantages in combining Actigard with commercial bacteriophages, the label rates of current bacteriophage preparations, like AgriPhage, are 10- to 20-fold less than what was used in those studies (Balogh et al. 2002; Obradovic et al. 2002). Therefore, similar efficacy of combining Actigard with commercial bacteriophage preparations may be difficult.

Based on our intensive research programs on bacterial spot in Wimauma, Quincy, and Gainesville and at several grower locations, the following recommendations have been made for bacterial spot management for fresh-market tomato production in Florida:

- Actigard and copper-mancozeb combination. Actigard needs to be applied every 7 days for optimum efficacy. The first application should be started as early as possible after transplanting. If you are using Actigard, it is important to reduce copper-mancozeb applications. Copper and/or mancozeb may still be needed for some fungal disease control. The label for Actigard has precautions to minimize yield suppression.

\section{Or:}

- Actigard and AgriPhage combination. This combination might help to eliminate or further reduce copper significantly for the management of bacterial spot. In this program, use Actigard every 7 days. Use phage twice a week and apply before sunset, especially before expected rains and/or immediately after. Copper and/or mancozeb may still be needed for some foliar fungal disease control. If you have never used Actigard and/or AgriPhage in your production, try it only in limited areas to determine its suitability. Read all label information carefully. Always 
use the cultural practices mentioned above as the backbone of your integrated program.

\section{Literature Cited}

Abrahamian, P., J. Jones, and G. Vallad. 2019 (forthcoming). "Efficacy of Copper and Copper Alternatives for Management of Bacterial Spot on Tomato under Transplant and Field Production." Crop Protection 126 (December). https:// doi.org/10.1016/j.cropro.2019.104919.

Araújo, E. R., J. R. Costa, M. A. S. V. Ferreira, and A. M. Quezado-Duval. 2012. "Simultaneous Detection and Identification of the Xanthomonas Species Complex Associated with Tomato Bacterial Spot Using Species-Specific Primers and Multiplex PCR." J. Appl. Microbiol. 113: 1479-1490.

Balogh, B., J. B. Jones, M. T. Momol, S. M. Olson, A. Obradovic, P. King, and L. E. Jackson. 2002. "Efficacy of Bacteriophage Formulations for Control of Bacterial Spot on Tomato." Phytopathology 92: S6.

Bouzar, H., J. B. Jones, G. V. Minsavage, R. E. Stall, and J. W. Scott. 1994. "Proteins Unique to Phenotypically Distinct Groups of Xanthomonas campestris pv. vesicatoria Revealed by Silver Staining." Phytopathology 84: 39-44.

Bouzar, H., J. B. Jones, R. E. Stall, N. C. Hodge, G. V. Minsavage, A. A. Benedict, and A. M. Alvarez. 1994. "Physiological, Chemical, Serological, and Pathogenic Analyses of a Worldwide Collection of Xanthomonas campestris pv. vesicatoria Strains." Phytopathology 84: 663-671.

Conover, R. A., and N. R. Gerhold. 1981. "Mixture of Copper and Maneb or Mancozed for Control of Bacterial Spot of Tomato and their Compatibility for Control of Fungus Diseases." Proc. Fla. State Hortic. Soc. 94: 154-156.

Cuppels, D. A., F. J. Louws, and T. Ainsworth. 2006. "Development and Evaluation of PCR-based Diagnostic Assays for the Bacterial Speck and Bacterial Spot Pathogens of Tomato." Plant Dis. 90: 451-458.

Doidge, E. M. 1920. “A Tomato Canker.” J. Dep. Agric. Union S. Afr. 1: 718-721.

Doidge, E. M. 1921. “A Tomato Canker." Ann. Appl. Biol. 7: 407-430.

Flaherty, J. E., J. B. Jones, B. K. Harbaugh, G. C. Somodi, and L. E. Jackson. 2000. "Control of Bacterial Spot on Tomato in the Greenhouse and Field with h-Mutant Bacteriophages." HortScience 35: 882-884.
Horvath, D. M., R. E. Stall, J. B. Jones, M. H. Pauly, G. E. Vallad, D. Dahlbeck, B. J. Staskawicz, and J. W. Scott. 2012. "Transgenic Resistance Confers Effective Field Level Control of Bacterial Spot Disease in Tomato." PloS One, 7(8): e42036.

Huang, C.-H., and G. E. Vallad. 2012. "Evaluation of Bactericides and Actigard for Management of Bacterial Spot of Tomato, Fall 2010." Plant Disease Management Reports 6: V039.

Huang, C.-H., G. E. Vallad, S. Zhang, A. Wen, B. Balogh, J. F. L. Figueiredo, F. Behlau, J. B. Jones, M. T. Momol, and S. M. Olson. 2012. "Effect of Application Frequency and Reduced Rates of Acibenzolar-S-methyl on the Field Efficacy of Induced Resistance against Bacterial Spot on Tomato." Plant Dis. 96: 221-227.

Ivors, K., D. Milks, and C. Holmberg. 2006. "Evaluation of Products for Control of Bacterial Spot on Tomato." In 22nd Annual Tomato Disease Workshop. 29.

Jones, J. B. 1991. "Bacterial Spot." In Compendium of Tomato Diseases, edited by J. B. Jones et al. 27. APS Press.

Jones, J. B., and J. P. Jones. 1985. “The Effect of Bactericides, Tank Mixing Time and Spray Schedule on Bacterial Leaf Spot of Tomato." Proc. Fla. State Hortic. Soc. 98: 244-247.

Jones, J. B., G. H. Lacy, H. Bouzar, R. E. Stall, and N. W. Schaad. 2004. "Reclassification of the Xanthomonads Associated with Bacterial Spot Disease of Tomato and Pepper." Syst. Appl. Microbiol. 27: 755-762.

Jones J. B., A. Obradovic, B. Balogh, M. T. Momol, and L. E. Jackson. 2002. "Control of Bacterial Spot on Tomato with Bacteriophages." Phytopathology 92: S108.

Jones J. B., K. L. Pohronezny, R. E. Stall, and J. P. Jones. 1986. "Survival of Xanthomonas campestris pv. vesicatoria in Florida on Tomato Crop Residues, Weeds, Seeds and Volunteer Tomato Plants." Phytopathology 76: 430-434.

Koenraadt, H., B. Van Betteray, R. Germain, G. Hiddink, J. B. Jones, and J. Oosterhof. 2009. "Development of Specific Primers for the Molecular Detection of Bacterial Spot of Pepper and Tomato." II International Symposium on Tomato Diseases. 808: 99-102.

Koller, W. 1998. "Chemical Approaches to Managing Plant Pathogens." In Handbook of Integrated Pest Management, edited by J. R. Ruberson. Dekker. 
Kucharek, T. 1994. Bacterial Spot of Tomato and Pepper. PP3. Gainesville: University of Florida Institute of Food and Agricultural Sciences. https://ufdc.ufl.edu/ IR00005294/00001.

Louws, F. J., M. Wilson, H. L. Cambell, D. A. Cuppels, J. B. Jones, P. B. Shoemaker, F. Sahin, and S. A. Miller. 2001. "Field Control of Bacterial Spot and Bacterial Speck of Tomato Using a Plant Activator." Plant Dis. 85: 481-488.

Ma, X., M. Lewis Ivey, and S. Miller. 2011. "First Report of Xanthomonas gardneri Causing Bacterial Spot of Tomato in Ohio and Michigan." Plant Dis. 95: 1584.

Marco, G. M., and R. E. Stall. 1983. "Control of Bacterial Spot of Pepper Initiated by Strains of Xanthomonas campestris pv. vesicatoria That Differ in Sensitivity to Copper." Plant Dis. 67: 779-781.

Obradovic, A., J. B. Jones, M. T. Momol, S. M. Olson, P. King, and B. Balogh. 2002. "Management of Tomato Bacterial Spot in the Field by Foliar Applications of Bacteriophages and SAR Inducers." Phytopathology 92: S60.

Obradovic, A., A. Mavridis, K. Rudolph, J. D. Janse, M. Arsenijevic, J. B. Jones, G. V. Minsavage, and J. F. Wang. 2004. "Characterization and PCR-based Typing of Xanthomonas campestris pv. vesicatoria from Peppers and Tomatoes in Serbia." Eur. J. Plant Pathol. 110: 285-292.

Pohronezny, K. L., M. A. Moss, W. Danker, and J. Schenk. 1990. "Dispersal and Management of Xanthomonas campestris pv. vesicatoria during Thinning of Direct Seeded Tomato." Plant Dis. 74: 800-805.

Potnis, N., S. Timilsina, A. Strayer, D. Shantharaj, J. D. Barak, M. L. Paret, G. E. Vallad, and J. B. Jones. 2015. "Bacterial Spot of Tomato and Pepper: Diverse Xanthomonas Species with a Wide Variety of Virulence Factors Posing a Worldwide Challenge." Mol. Plant Pathol. 16: 907-920.

Ritchie, D. F. 2000. "Bacterial Spot of Pepper and Tomato." The Plant Health Instructor. Retrieved from American Phytopathology Society. Updated 2007. Accessed October 9, 2015. https://www.apsnet.org/edcenter/disandpath/ prokaryote/pdlessons/Pages/Bacterialspot.aspx.

Stall, R. E., J. B. Jones, and G. V. Minsavage. 2009. "Durability of Resistance in Tomato and Pepper to Xanthomonads Causing Bacterial Spot." Annu. Rev. Phytopathol. 47:

265-284.
Sticher, L., B. Mauch-Mani, and J. P. Métraux. 1997. "Systemic Acquired Resistance." Annu. Rev. Phytopathol 35: 235-270.

Strayer, A. L., A. Jeyaprakash, G. V. Minsavage, S. Timilsina, G. E. Vallad, J. B. Jones, and M. L. Paret. 2016. "A Multiplex Real-Time PCR Assay Differentiates Four Xanthomonas Species Associated with Bacterial Spot of Tomato." Plant Dis. 100: 1660-1668.

Strayer-Scherer, A. L., Y. Y. Liao, M. Young, L. Ritchie, G. E. Vallad, S. Santa, J. H. Freeman, D. Clark, J. B. Jones, and M. L. Paret. 2017. "Advanced Copper Composites against Copper-Tolerant Xanthomonas perforans and Tomato Bacterial Spot." Phytopathology 108: 196-205.

Thayer, P. L., and R. E. Stall. 1961. "A Survey of Xanthomonas vesicatoria Resistance to Streptomycin." Proc. Fla. State Hortic. Soc. 75: 163-165.

Thayer, P. L., and R. E. Stall. 1962. "Streptomycin Resistance of the Bacterial Spot Pathogen and Control with Streptomycin." Plant Dis. 46: 389-392.

US Environmental Protection Agency (EPA). 2009. Reregistration Eligibility Decision (RED) for Coppers. EPA 738-R-09-304. May 2009.

Vallad, G. E., K. L. Pernezny, and T. Momol. 2004. A Series on Disease in the Florida Vegetable Garden: Tomato. PP200. Gainesville: University of Florida Institute of Food and Agricultural Sciences. https://edis.ifas.ufl.edu/pp121.

Vallad, G. E., K. L. Pernezny, B. Balogh, A. Wen, J. F. L. Figueiredo, J. B. Jones, R. M. Muchoverj, N. Havranek, N. Abdallah, S. Olson, and P. D. Roberts. 2010. "Comparison of Kasugamycin to Traditional Bactericides for the Management of Bacterial Spot on Tomato." HortSci. 45: 1834-1840.

Wade, L., and A. Kurtz. 2006. "Kasugamycin - Review of a Novel Antibiotic to the United States." Tomato Disease Workshop Proceedings. 27-29.

Willson, M., H. L. Campbell, J. B. Jones, T. V. Suslow, and D. A. Cuppels. 1997. "Biological Control of Bacterial Speck of Tomato.” Phytopathology 86: S49. 